Артьомова // Економічна теорія.- 2011.- №2. C. $16-26$

9. Геєць В. Довіра як елемент соціального капіталу в економічному розвитку України / В. Геєць // Економічна теорія. - 2010.- № 3 - С.7-19.

10. Белик А. Экономическая антропология: взаимодействие экономики и культуры/ А. Белик // Экономический журнал.- 2010.-№4(20).

11. Zbignew Brzezinski. Out of Control. Global Turmoil on the Eve of the Twenty First
Century / Brzezinski Zbignew. - New York, Charles Scribner's sons, 1993

12. Гриценко А. Капитализация экономики в ретроспективе и перспективе /А.Гриценко // Методологія, теорія та практика соціологічного аналізу сучасного суспільства. 2009. - Вип. 15. C.191-195.

13. Социализация экономики - выход из тупика? [Електронний ресурс]. - Режим доступу: http://newsland.com/news/detail/id/649460/

Рецензент д.е.н., професор ХНАДУ Горєлов Д.О. Експерт редакційної колегії к.е.н., доцент УкрДАЗТ Полякова О.Н.

УДК 336.71

\title{
ДОСЛІДЖЕННЯ ЗАРУБІЖНОГО ТА ВІТЧИЗНЯНОГО ДОСВІДУ РЕЙТИНГОВОГО ОЦІНЮВАННЯ НАДІЙНОСТІ КОМЕРЦІЙНОГО БАНКУ
}

\author{
Фурсова В.А., к.е.н., доцент, \\ Півненко Т.Ю., магістр (НАУ Національний ім. М. С. Жуковського «ХАІ»)
}

\begin{abstract}
Економічна криза негативно впливає на фінансову стійкість банків. Для своєчасного виявлення проблем банку та прийняття необхідни управлінських заходів дуже важливе значення мають рейтингові методики оцінювання його надійності. В статті розглянуті вітчизняні й зарубіжні методики оцінювання фінансової стійкості банків, виявлені їх недоліки та переваги, надані рекомендації щодо їхнього подальшого удосконалення.
\end{abstract}

Ключові слова: комерційний банк, рейтингове оціюнювання, фінансова стійкість, статистичні моделі, банківські ризики.

\section{ИССЛЕДОВАНИЕ ЗАРУБЕЖНОГО И ОТЕЧЕСТВЕННОГО ОПЫТА РЕЙТИНГОВОЙ ОЦЕНКИ НАДЕЖНОСТИ КОММЕРЧЕСКОГО БАНКА}

\author{
Фурсова В.А., к.э.н., доцент, \\ Пивненко Т.Ю., магистр (НАУ Им. Н. Е. Жуковского «ХАИ»)
}

\begin{abstract}
Экономический кризис негативно влияет на финансовую устойчивость банков. Для своевременного выявления проблем банка и принятия необходимых управленческих мероприятий очень важное значение имеют рейтинговые методики оценки его надежности. В статье рассмотрень отечественные и зарубежные методики оценки финансовой устойчивости банков, выявлены их недостатки и преимущества, даны рекомендации по их дальнейшему усовершенствованию.
\end{abstract}

Ключевые слова. Коммерческий банк, рейтинговая оценка, финансовая устойчивость, статистические модели, банковские риски.

\section{THE ANALYSIS OF FOREIGN AND DOMESTIC EXPERIENCE RATING EVALUATION OF STABILITY OF COMMERCIAL BANK}

Fursova V.A., Ph.D. of economic sciences, associate professor, Pivnenko T. Y., holder of Master's

( National Aerospace University named after N.E. Zhukovskiy "Kharkiv Aviation Institute»)

The political and economic crisis has a negative impact on the financial stability of commercial banks. For timely identification of problems the bank and take the necessary administrative measures are very 
important rating methodology for its reliability. The article considers the domestic and foreign approaches to the assessment of financial stability of the Bank, found their advantages and disadvantages, given recommendations for their further improvement. Analysis of foreign methodologies evaluation indicates that foreign techniques give the most attention of risk assessment, such as credit and market. In the Ukrainian methodologies the market risk is not considered at all. However, both foreign and Ukrainian rating methodology for assessing are considered liquidity, capital adequacy and profitability.

Keywords. Commercial Bank, rating, financial stability, statistical models, banking risks.

Постановка проблеми та ї̈ зб'язки 3 науковими чи практичними завданнями. В умовах нестабільної економічної та політичної ситуації в Україні, спостерігається різке погіршення діяльності банківської системи, що призвело до банкрутства багатьох банків. Так, за 11 місяців 2014 р. Національним банком України було прийнято рішення щодо ліквідації 14 комерційних банків, визнано неплатоспроможними - 12, до того ж 47 банків (28\% від банківської системи у цілому) мали збитки за 9 місяців роботи [1]. Враховуючи те, що проблеми у діяльності банківських установ негативно впливають на фінансовий стан всіх економічних суб'єктів вкрай необхідним є дослідження питання щодо методик оцінювання фінансової стійкості та надійності банків.

Аналіз останніх досліджень і публікацій та виділення невирімених частин загальної проблеми. Різні методики рейтингового оцінювання фінансової стійкості та надійності банків розглядаються в працях економістів О.В.Дзюблюк, Р.В. Михайлюк, Б. Пшик, А. Стефанишиної, Л. Примостки [2-5] та інших. Але незважаючи на значну кількість публікацій, досліджувана тема є недостатньо опрацьованою в економічній літературі, оскільки майже не розглядаються методики оцінювання надійності банків в умовах фінансової кризи, не виділено особливості та відмінності вітчизняних та зарубіжних методик, не враховуються показники розміру активів банку.

Постановка завдання. Метою статті $\epsilon$ дослідження вітчизняних й зарубіжних підходів щодо рейтингового оцінювання надійності банків та

визначення їхних недоліків та переваг.

Виклад основного матеріалу

досліджсення. Рейтингова оцінка надійності банка - це комплексний підхід до визначення фінансового стану кожного банку та виявлення основних закономірностей його розвитку. Надійний банк - це банк, який забезпечує інтереси кредиторів, вкладників та інвесторів, керується принципами партнерських взаємовигідних відносин, проводить політику у інтересах розвитку суспільства, стійкий до внутрішніх та зовнішніх погроз.

На відміну від українських банків, зарубіжні банківські установи вже декілька десятиліть використовують у своїй діяльності рейтингове оцінювання, але в останні роки спостерігалися суттєві зміни в оцінюванні ними фінансового стану банків. Це, в основному, було обумовлено світовою фінансовою кризою.

Системи зарубіжного рейтингового оцінювання класифікують наступним чином (таблиця 1) [2]: 1) рейтингові системи оцінки діяльності банків (CAMELS, PATROL, O.R.A.P.); 2) системи фінансових коефіцієнтів і групового аналізу (BAKIS); 3) комплексні системи оцінки банківських ризиків (RAST, RATE); 4) статистичні моделі, наприклад моделі типу «банкрутствоадаптація-стійкість» (SAABA).

Порівняльний аналіз українських та россійських рейтингових методик за набором показників наведено у таблиці 2 [2-6].

Так, методика Кромонова базується на використанні індексного методу та передбачає розрахунок поточного індексу надійності на основі 6 параметричних коефіцієнтів (генеральний коефіцієнт надійності, миттєвої ліквідності, кроскоефіцієнт, генеральний коефіцієнт ліквідності, показник захищеності капіталу та фондової капіталізації прибутку) [2]. Крім того, розраховується синтетичний індекс надійності, що дає можливість вирівняти обумовлені випадковими подіями коливання поточного індексу.

Методика О.Б. Ширинської - включає розрахунок 12-ти параметрів балансу банку. Обчислюється п'ять видів диференційованих коефіцієнтів, що характеризують структуру активів і пасивів банку, рівень його ліквідності, надійності та рентабельності. Далі визначається синтетичний коефіцієнт через систему зважених часткових коефіцієнтів [2].

Методика RAFINS містить розрахунок 15 коефіцієнтів для оцінювання надійності банку 3 іноземним капіталом, який знаходиться в Україні, та 15 показників для оцінки його материнського банку [6].

Методики РА «Експерт - Україна», «Кредит-Рейтинг» - $€$ методиками приватних агенств $[7,8]$.

Висновки даного дослідження $i$ перспективи подальших робіт у цьому напрямку. Аналіз наведених вище порівняльних характеристик вітчизняних та зарубіжних методик рейтингового оцінювання свідчить про те, що іноземні методики приділяють найбільшу увагу оцінки ризиків, а саме кредитному та ринковому. В українських методиках ринковий ризик не 
враховується зовсім. Проте ліквідність, достатність зарубіжних, так i вітчизняних підходах щодо капіталу та рентабельність аналізується, як в рейтингової оцінки фінансового стану банку.

Таблиияя 1

Системи оцінки ризиків та раннього реагування в країнах світу

\begin{tabular}{|c|c|c|c|}
\hline $\begin{array}{c}\text { Країна, } \\
\text { наглядо- } \\
\text { вий орган }\end{array}$ & $\begin{array}{l}\text { Система } \\
\text { нагляду }\end{array}$ & Показники & Тип системи \\
\hline \multirow{2}{*}{$\begin{array}{c}\text { Франція, } \\
\text { Банківська } \\
\text { комісія }\end{array}$} & ORAP & $\begin{array}{l}\text { Розраховують } 14 \text { показників, які поділяють на } 5 \text { груп: } \\
\text { 1) пруденційні коефіцієнти (аналіз капіталу, ліквідності } \\
\text { тощо); } \\
\text { 2) коефіцієнти балансової та позабалансової діяльності; } \\
\text { 3) показники безнадійної заборгованості, якості } \\
\text { активів; } \\
\text { 4) ринкові ризики; } \\
\text { 5) коефіцієнти, що характеризують доходи. }\end{array}$ & $\begin{array}{l}\text { Дистанційна } \\
\text { рейтингова } \\
\text { система }\end{array}$ \\
\hline & SAABA & $\begin{array}{l}\text { Складається з трьох модулів: } \\
\text { 1) оцінюють якість кредитного портфелю; } \\
\text { 2) аналізують фінансовий стан власників акцій банку та } \\
\text { їхню спроможність підтримувати банк у разі виникнення } \\
\text { фінансових труднощів; } \\
\text { 3) проводять діагностику якості менеджменту банку, } \\
\text { внутрішнього аудиту та ліквідності. }\end{array}$ & $\begin{array}{l}\text { Система } \\
\text { раннього } \\
\text { реагування - } \\
\text { очікувані збитки }\end{array}$ \\
\hline $\begin{array}{c}\text { Німеччина, } \\
\text { Федеральне } \\
\text { відомство } 3 \\
\text { контролю над } \\
\text { банками } \\
\end{array}$ & BAKIS & $\begin{array}{l}\text { Складається із } 47 \text { показників, із яких: } 19 \text { - } \\
\text { характеризують кредитний ризик і платоспроможність; } \\
16 \text { - оцінюють ринковий ризик; } 2 \text { - відносять до } \\
\text { ринкових ризиків; } 10 \text { - оцінюють прибутковість банка. }\end{array}$ & $\begin{array}{l}\text { Система } \\
\text { фінансових } \\
\text { коефіцієнтів та } \\
\text { аналізу окремих } \\
\text { груп банків }\end{array}$ \\
\hline $\begin{array}{c}\text { Італія, Банк } \\
\text { Італії }\end{array}$ & PATROL & $\begin{array}{l}\text { Розраховують } 5 \text { компонентів: } \\
\text { 1) достатність капіталу; } \\
\text { 2) прибутковість; } \\
\text { 3) якість кредитів; } \\
\text { 4) організація; } \\
\text { 5) ліквідність. }\end{array}$ & $\begin{array}{l}\text { Дистанційна } \\
\text { рейтингова } \\
\text { система }\end{array}$ \\
\hline $\begin{array}{l}\text { Нідерланди, } \\
\text { Банк } \\
\text { Нідерландів }\end{array}$ & RAST & $\begin{array}{l}\text { Система комплексної оцінки банківських ризиків RAST } \\
\text { містить наступні блоки: } \\
\text { 1) фінансовий аналіз банку на основі офіційної } \\
\text { статистичної звітності та даних перевірок; } \\
\text { 2) розмежування банківської установи за управлінськими } \\
\text { підрозділами і видами діяльності; } \\
\text { 3) оцінка ризиків на рівні підрозділів; } \\
\text { 4) агрегування показників і складання звітів. }\end{array}$ & $\begin{array}{l}\text { Комплексна } \\
\text { система для } \\
\text { оцінки ризиків }\end{array}$ \\
\hline $\begin{array}{c}\text { Велико- } \\
\text { британія, } \\
\text { Відомство } 3 \\
\text { фінансової } \\
\text { політики } \\
\end{array}$ & RATE & $\begin{array}{l}\text { Система RATE включає такі блоки: } \\
\text { 1) оцінка ризику; } \\
\text { 2) інструменти нагляду; } \\
\text { 3) оцінка ефективності застосування інструментів } \\
\text { нагляду. }\end{array}$ & $\begin{array}{l}\text { Комплексна } \\
\text { система оцінки } \\
\text { банківських } \\
\text { ризиків }\end{array}$ \\
\hline $\begin{array}{c}\text { США, } \\
\text { Федеральна } \\
\text { резервна } \\
\text { система }\end{array}$ & CAMELS & $\begin{array}{l}\text { Система CAMELS оцінює ризики та визначає } \\
\text { рейтингові оцінки за } 6 \text { компонентами: } \\
\text { 1) достатність капіталу (C); } \\
\text { 2) якість активів (A); } \\
\text { 3) менеджмент (M); } \\
\text { 4) надходження (E); } \\
\text { 5) ліквідність (L); } \\
\text { 6) чутливість до ринкового ризику (S). }\end{array}$ & $\begin{array}{l}\text { Система } \\
\text { рейтингів на базі } \\
\text { інспекційних } \\
\text { перевірок на } \\
\text { місцях }\end{array}$ \\
\hline
\end{tabular}

Складено авторами за даними [2]

Вісник економіки транспорту і промисловості № 49, 2015 
Порівняльний аналіз методик оиінки надійності банку

\begin{tabular}{|c|c|c|c|c|c|c|c|c|}
\hline \multirow{2}{*}{\multicolumn{2}{|c|}{ Групи показників }} & \multicolumn{7}{|c|}{ Рейтингові методики } \\
\hline & & 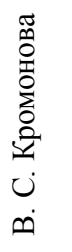 & 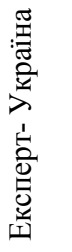 & 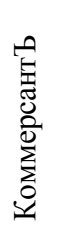 & 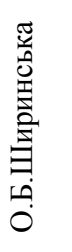 & 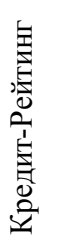 & 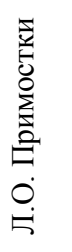 & $\frac{\mathscr{Z}}{\underset{Z}{Z}}$ \\
\hline \multicolumn{2}{|l|}{ Капітал } & + & + & + & + & + & + & + \\
\hline \multirow[t]{2}{*}{$\begin{array}{l}\text { Якість } \\
\text { активів }\end{array}$} & Прострочені кредити & - & - & + & - & + & - & + \\
\hline & Структура активів & - & + & + & + & + & + & + \\
\hline \multicolumn{2}{|c|}{ Рентабельність } & - & + & - & + & + & - & + \\
\hline \multicolumn{2}{|c|}{ Ліквідність } & + & + & + & + & + & + & + \\
\hline \multicolumn{2}{|c|}{ Виконання нормативів } & - & - & - & - & + & - & - \\
\hline \multirow[t]{5}{*}{ Ризики } & Ліквідності & + & + & + & + & + & + & + \\
\hline & Кредитний & - & - & - & + & + & + & + \\
\hline & Процентний & - & - & - & - & + & + & - \\
\hline & Валютний & - & - & - & - & + & + & - \\
\hline & Інші ризики & - & - & - & - & - & - & - \\
\hline \multicolumn{2}{|c|}{ Менеджмент } & - & - & - & - & - & - & - \\
\hline \multicolumn{2}{|c|}{ Масштаб роботи } & - & + & - & - & - & - & + \\
\hline \multicolumn{2}{|c|}{$\begin{array}{l}\text { Показники роботи материнської } \\
\text { компанії }\end{array}$} & - & - & - & - & - & - & + \\
\hline \multicolumn{2}{|c|}{ Клієнтська база } & - & - & - & - & + & - & + \\
\hline
\end{tabular}

Розроблено авторами за даними [2-8]

Серед українських методик найбільш повний аналіз діяльності банківської установи відображено у PA «Кредит-Рейтинг» та RAFINS. Як свідчить аналіз вітчизняних рейтингових методик - тільки дві із розглянутих методик враховують масштаб роботи банку, і тільки одна методика має спеціальні показники щодо оцінювання надійності банку 3 іноземним капіталом.

Таким чином, в подальших дослідженнях рейтингових методик щодо визначення рівня надійності українських банків слід придиліти більше уваги питанням оцінювання ризиків та масштабу діяльності банку.

\section{СПИСОК ЛІТЕРАТУРИ}

1. Основні показники діяльності банків України [Електронний ресурс]. - Режим доступу: http://www.bank.gov.ua/control/uk/publish/article?art_id=75 473 \& cat id $=40259$.

2. Дзюблюк, О.В. Фінансова стійкість банків як основа ефективного функціонування кредитної системи
[Текст]: монографія / О.В.Дзюблюк, Р.В. Михайлюк. Тернопіль, 2009. - 316 с.

3. Пшик, Б. Актуальні проблеми рейтингового оцінювання діяльності банків в Україні [Текст] // Б. Пшик / Вісник Університету банківської справи Національного банку України. - 2014. - № 2 (20). C. $149-152$.

4. Стефанишина, А. Характеристика та аналіз методик оцінювання стійкості банків України та зарубіжжя [Текст] / А. Стефанишина // Вісник НБУ. 2010. - № 11. - С. 62 - 66 .

5. Примостка, Л. Методика аналізу фінансової стійкості банку за допомогою динамічного нормативу [Текст] /Л. Примостка // Вісник Національного банку України. - 2002. - №10. - С.40 - 45.

6. Фурсова, В. Рейтингова систем оцінки фінансової стабільності банків з іноземним капіталом як інструмент підвищення надійності банківської системи [Текст] // В. Фурсова, О. Каширіна / Вісник НБУ. - 2011. - № 9. - С. 33 - 41 .

7. Рейтинг надежности банков РА «Експерт Україна» [Електронний ресурс]. - Режим доступу: http://www.expert.ua/articles/7/0/8708.

8. Рейтинги депозитов банков РА «КредитРейтинг» [Електронний ресурс]. - Режим доступу:http://www.credit-rating.ua/ru/ratings/object/24.

Рецензент д.е.н., професор ХНЕУ Гавкалова Н.Л. Експерт редакційної колегії к.е.н., доцент УкрДАЗТ Токмакова І.В. 